(12) That the council has a duty to promote regional and international co-operation, to elaborate the scientific parts of bilateral and international cultural agreements and to represent the country in international scientific non-governmental organizations.

(13) That the Member States grant sufficient means for the exchange of their professors and scientific workers and request Unesco to anticipate in its budget for 1963-64 a supplementary provision to accomplish this aim.

(14) That the Member States promote organization of national or regional scientific congresses and symposia as well as participation in international meetings.

(15) That the Member States support their scientific institutions in co-operation with similar establish- ments in other countries to solve problems of regional or international importance.

(16) That Unesco should continue to promote the organization of symposia and regional scientific meetings to discuss subjects of interest to various Member States.

(17) That all efforts and results reached by science should be used solely to help humanity and to improve the standard of living of the peoples.

(18) The conference thanks the Middle East Science Co-operation Office of Unesco, the Science Council of the United Arab Republic as well as the international consultants, and recommends that Unesco should organize within two years a similar conference to study the progress made in the field of scientific research in the Member States.

\title{
ELECTRICAL ENGINEERING IN THE ROYAL NAVY
}

$\mathrm{A}^{\mathrm{T}}$ T almost the same time as he relinquished, by retirement, the post of director of electrical engineering at the Admiralty, Sir Hamish Maclaren assumed office as president of the Institution of Electrical Engineers. This is only the second occasion on which the chief electrical engineer of the Admiralty has occupied the presidential chair of the Institution. C. H. Wordingham, who became head of the Electrical Engineering Department of the Admiralty in 1903, was president of the Institution during 1916-18.

Very appropriately, in his presidential address delivered on October 6, Sir Hamish reviewed the development of electrical engineering in the Royal Navy. The electronic equipment and control gear of the submarine utilizing nuclear propulsion plant represents the culmination of some ninety years of development of the applications of electricity in naval vessels, the first being the electrical firing of guns. It was, however, nearly twenty years earlier that the Admiralty made its earliest uses of electrical signalling when in 1852 the twenty-two semaphore stations between Plymouth and Whitehall were replaced by an electric telegraph.

The first dynamo was installed in a warship in 1875 to provide power for a searchlight to be used against torpedo craft, and it is probably this early association with torpedoes that established the practice of placing the responsibility for all electrical equipment in ships on the torpedo officer. This practice remained in force until 1946 when the electrical branch was founded.

A combined ship lighting and searchlight installation was fitted in H.M.S. Inflexible in 1881, Swan incandescent lamps being connected in groups in series. By 1886 first-class ships were being equipped with three dynamos each supplying 200 amp. at $80 \mathrm{~V}$.

The ring-main system of distribution at $22-\mathrm{V}$. direct current was introduced in the early years of the present century and remained the standard naval practice until after the end of the Second World War.

It was in 1896 that the remarkable pioneering experiments in wireless telegraph communication between ships were made by Captain H. B. Jackson. Communication was established between H.M.S.'s Defiance and Scourge over a range of 5,800 yards. In 1899 Marconi equipment with a range of up to seventy miles was installed in four ships.
Experience during action in the First World War focused attention on the impracticability of maintaining so-called watertight enclosures watertight, and means were devised for isolating, automatically, flooded equipment from the supply.

After the War the Admiralty reviewed the experience, to date, of electricity supply in warships and in particular considered the possible introduction of alternating current. Considerable importance, perhaps an undue amount, was attached to the ease and convenience of speed variation of the direct current motor and direct current was retained.

The application of electricity in fire control systems was greatly advanced during the First World War. Individual components such as plotting tables, data transmission and communication instruments had, however, been developed largely by individual specialist firms, giving rise to diversity of design and practice.

It was towards the end of the First World War that the gun director system was introduced in which a gyroscope was employed as a stable reference to ensure that the guns fired only when the ship was in a horizontal position during rolling. This was a prelude to the day when directors and gun mountings would themselves be stabilized.

Between the two World Wars action was taken towards achieving uniformity of practice in instrumentation. Much effort was directed towards the design of fire control computers, and, as the importance of air attack increased, to the special problems associated with the control of high-angle anti-aircraft guns. Of the work done at the Admiralty Research Laboratory during that period mention should be made of the plotting table which automatically records the ship's position on a chart, of the 'magslip', a data-transmission unit of much greater accuracy than any other available at that time, and of an electrically controlled oil-operated remote-power system for searchlights.

The outbreak of the Second World War produced immediately the problem of combating the novel and ingenious devices which had been developed by the enemy. The first was the magnetic mine. Real success in sweeping the magnetic mine was achieved with the development of the towed buoyant-cable sweep whereby a relatively large magnetic field is produced in the sea by circulating current pulses of 
several thousand amperes round the loop of buoyant cable.

The degaussing of ships, at first effected by a singleturn coil embracing the hull, was, after considerable research, shown to be practicable with multi-core cable fitted inside the hull.

H.M.S. Belfast, damaged by a magnetic mine explosion in October 1939, exhibited extensive damage to electrical equipment from underwater shock. The shock accelerations and displacements resulting from non-contact under-water explosions were of a much higher order than those against which the equipment had been designed, and an extensive programme of experiment and of redesign of electrical equipment and of shock-proof mountings was undertaken.

The loss of the Ark Royal in November 1941 brought to light further important factors in the vulnerability of the electrical systems of warships. A hit by a single torpedo had the disastrous result of flooding one boiler room and the main switchboard room. The remote control of circuit breakers from the main switchboard was based on a system which the flooding rendered completely inoperative and services could not be restored although power was available for some time. Even the power supply was dependent, as the generators were driven by steam turbines, on the ship's main boilers. The redesign of the control system introduced relay control, energized from independent local supplies, and auxiliary diesel generators were provided.

Electrical actuation in the training and elevation of anti-aircraft guns was initiated in 1939 , utilizing the rotating amplifier machine known as the 'metadyne', controlled by a magslip-data transmission system to which reference has already been made.

The introduction of radar for range-finding produced automatic following of the radar aerial so that the arrial, the gun director and hence the gun automatically followed the target. Fully automatic following of the target was achieved by designing the radar to provide its own misalignment signal and feeding the necessary additional information from the fire control computer and the stabilizer.

The action information centre has become the most concentrated part of the electrical installation of a warship. It is the focal point for radar and asdic information, for external and internal communication, aircraft and weapon direction and for navigation.

Alternating current was adopted in 1948 for all ships larger then mine-sweepers. Simplicity, reliability and the necessity to save space and weight in the large and complex electrical systems required made the advantages of alternating current supply overwhelming.

A supply frequency of $60 \mathrm{c} . / \mathrm{s}$. was adopted for the $440 \mathrm{~V}$. three-phase system. The higher frequency of $60 \mathrm{c} . / \mathrm{s}$, in place of the standard power frequency of $50 \mathrm{c} . / \mathrm{s}$. , had the great merit of a substantial reduction in the size and weight of machines and a higher maximum speed of 1,800 revolutions per minute. There was the added advantage of a common standard with the U.S. Navy. There is, of course, the disadvan. tage of more complex equipment where continuous variation of speed is required. Automatic voltage regulation is required, and a standard type of automatic voltage regulator utilizing a magnetic amplifier has been developed which can be used with generators of $150-\mathrm{kW} .-1,500-\mathrm{kW}$. capacity.

Nuclear propulsion has revolutionized the performance of the submarine, which becomes at last a true submarine rather than just a submersible vessel. The nuclear submarine must, however, still have a battery for starting up and emergency standby although of smaller size than that for the conventional submarine. Because of the possibility of prolonged submerged operation, some of the battery problems encountered with conventional submarines became of even greater importance. The evolution of hydrogen on open circuit can be reduced by the use of grid alloys having a very low antimony content. Antimony-free grids would at the same time eliminate the production of the highly toxic gas, antimony trihydride, or stibine.

The electrical installation of the nuclear submarine is in fact much like that of the surface vessel with the addition of an electric drive of small power for emergency use. As in the surface vessel, an increasing amount of electronic and servo equipment is required, and there is in addition the equipment for reactor control and instrumentation. It is in the submarine, because of the acute limitation of space, that semiconductor devices offer special promise in their future application.
J. GREIG

\section{POWDER METALLURGY}

$\mathrm{A}^{\mathrm{N}}$ $\mathrm{N}$ international conference on "Powder Metallurgy", sponsored by the Metal Powder Industries Federation and the Metallurgical Society of the American Institute of Mining and Metallurgical Engineers, was held in New York during June 13-17. At sessions throughout the first three days, papers were presented by authors and briefly discussed. Visits to plants were made during the last two days. The meetings were well managed and held to a precise time schedule which allowed little time for informal discussion. The hall, with a seating capacity of about four hundred, was filled for every session.

Dr. P. Schwarzkopf, honorary chairman of the conference, opened it with a review of a half-century of modern powder metallurgy, which he considers to have developed since Coolidge's paper of 1910 on the powder metallurgy of tungsten. $\mathrm{He}$ regards earlier powder metallurgy, such as that in pre-history, that by the Incas, and the British and Russian work on platinum, as detached from the development of modern technology to which they made little contribution. Powder metallurgy was a forgotten art at the start of this century, although in 1898 Welsbach patented its use to make osmium filaments. Coolidge's tungsten filaments were the first really usable product of modern powder metallurgy. Cemented carbides manufactured by powder methods came in 1922 .

Work on the nature of the sintering process appeared in 1922 when Sauerwald published his first paper on the subject, which he thought of as a recrystallization process. Important later work on the theory of sintering included Russian papers published in 1945 and the work of S. P. Slater and G. C. Kuczynski. In recent times the latter worker has dominated thinking in this field. 